\title{
Hitting HIV where it hides
} Andrew I Dayton

Address: Laboratory of Molecular Virology, Division of Emerging and Transfusion Transmitted Diseases, OBRR/CBER/FDA, HFM 315, 1401 Rockville Pike, Rockville, MD 20852-1448, USA

Email: Andrew I Dayton - Andrew.dayton@fda.hhs.gov

Published: I February 2008

Retrovirology 2008, 5:15 doi:10.1186/1742-4690-5-15

This article is available from: http://www.retrovirology.com/content/5/I/I5

(C) 2008 Dayton; licensee BioMed Central Ltd.

This is an Open Access article distributed under the terms of the Creative Commons Attribution License (http://creativecommons.org/licenses/by/2.0), which permits unrestricted use, distribution, and reproduction in any medium, provided the original work is properly cited.
Received: 30 January 2008

Accepted: I February 2008

\begin{abstract}
The recent finding that inhibitors of PI3/Akt can sensitize HIV infected macrophages to oxidative stress-induced cell death suggest a potential new therapeutic approach to targeting HIV reservoirs.
\end{abstract}

Although antiretroviral therapy has achieved laudable successes in combating HIV, particularly since the advent of protease inhibitors in the mid 1990s, fully successful treatment remains plagued by multiple, clinically latent viral reservoirs largely impervious to antiretroviral drugs. The microbiology of clinical latency is controversial and may involve elements of viral quiescence (expression of no - or a limited subset of - viral genes) as well as low level viral replication in protected cell types or anatomical compartments [1]. Viral persistence has been reported in brain cells (including perivascular macrophages, parenchymal microglial cells and astrocytes), NK cells, renal tubular cells, mononuclear cells from semen, follicular dendritic cells, cells of the monocyte/macrophage lineage (recently infected monocytes and tissue macrophages) and resting CD4+ T cells, with the latter two being the best known reservoirs [2-5].

Attempts at attacking the resting CD4+T cell HIV reservoir have generally involved induction (of presumably quiescent virus) with IL-2, IL-7, phorbol esters, or valproic acid $[3,6,7]$. Such induction approaches usually assume the activated, HIV producing cells will be killed directly by the induced virus or by the host immune system but some have attempted bolstering these effects by targeting immunotoxins to viral determinants [7]. The risk of a spreading infection by virus newly induced to replicate is generally mitigated in these scenarios by HAART.
Attacking the macrophage HIV reservoir has proven a thornier issue. From the virus's standpoint macrophages are an ideal reservoir cell because they are long lived, because HIV does not kill macrophages by direct lysis, as it does $\mathrm{CD} 4+\mathrm{T}$ cells, and because virus production by chronically infected macrophages tends to be relatively insensitive to a variety of antiretroviral agents [8-13]. Besides hosting a significant virus reservoir, chronically infected macrophages and/or their brain counterparts, microglia, may contribute to pathogenesis through chronic aberrant release of a variety of host and viral cytoactive factors and may be subject to chronic dysregulation through aberrant expression of surface receptors [14-20]. Thus, the recent report that PI3K/Akt inhibitors can drastically sensitize HIV infected macrophages to oxidative-stress-induced cell death [21] is welcome news as delineating a possible novel therapeutic approach.

HIV infection in vivo increases levels of superoxide anion and peroxynitrite, the latter of which can promote HIV replication in macrophages[22]. Recently Chugh et al. [23] reported that HIV infection activated the PI3K/Akt pathway exerting a cytoprotective effect against apoptotic challenge in a microglial cell line and in primary human macrophages. This described a pathway by which HIV could protect certain HIV infected cells against the oxidative stress they typically endure in vivo due to the high levels of nitric oxide (NO) they produce [24-27]. The finding 
that a variety of PI3K/Akt inhibitors, including wortmannin, Akt inhibitors IV \& VIII (Calbiochem) and the clinically available Miltefosine could all promote cell death in cultures of primary human macrophages infected with HIV, but not in uninfected controls, makes therapeutically attacking the HIV macrophage/microglial reservoir a tantalizing possibility.

Recent work has contributed significantly to understanding the roles of numerous HIV regulatory proteins in cells of lineages other than the T lineage $[22,28,29]$ and the work highlighted here is no exception. Mechanistic studies determined that the HIV Tat can mediate the activation of the PI3K/Akt pathway, dependent upon the Tat basic domain (a region that binds p53 [21,23]) and that the mediation is associated with a drop in the level of PTEN (phosphatase tensin homolog) protein expression. SIV Tat was also shown to mediate the cytoprotective effect (in a microglial cell line), suggesting an evolutionarily conserved role. The results are consistent with a model in which Tat competes with PTEN for p53 binding, causing p53 destabilization and a consequent reduction in PTEN mRNA and protein levels, relieving the PTEN inhibition of Akt activation (Figure 1).

Missing from the current in vitro findings is evidence that endogenous production of reactive oxygen species (ROS) in HIV infected macrophages or microglia is sufficient to render them more susceptible than uninfected control cells to oxidative stress-induced cell death $[30,31]$. Rather,

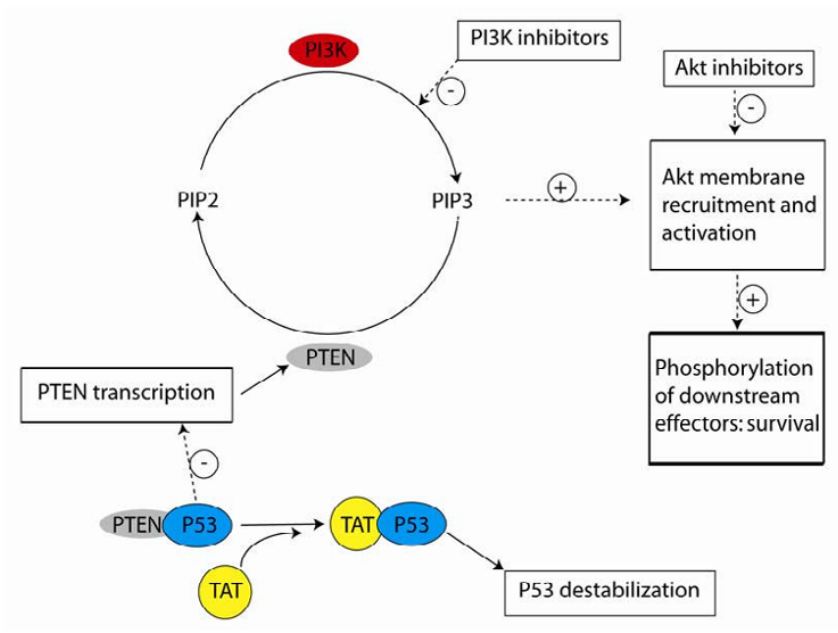

Figure I

Proposed pathways [2I] describing the effects of Tat and $\mathrm{PI}$ KK/Akt inhibitors on macrophage resistance to oxidative stress. Solid lines represent the flux of indicated molecular species. Dashed lines represent stimulatory $(+)$ or inhibitory $(-)$ regulation. Boxes enclose summaries of processes or effects. exogenous NO must be provided in vitro (in the form of sodium nitroprusside) $[21,23]$. Thus, for the suggested approach to succeed clinically, either in vivo levels of ROS in critical local compartments must be sufficient to cause death when the Akt pathway is inhibited - the likelihood of which is undetermined - or such levels of ROS must be induced - which is problematic. Time will tell.

\section{Acknowledgements}

The author thanks Indira Hewlett for a critical reading of the manuscript. The findings and conclusion in this article have not been formally disseminated by the Food and Drug Administration and should not be construed to represent any Agency determination or policy.

\section{References}

I. Sedaghat AR, Siliciano RF, Wilke CO: Low-level HIV-I replication and the dynamics of the resting $C D 4+T$ cell reservoir for HIV-I in the setting of HAART. BMC Infect Dis 2008, 8(I):2.

2. Crowe $S$, Zhu T, Muller WA: The contribution of monocyte infection and trafficking to viral persistence, and maintenance of the viral reservoir in HIV infection. J Leukoc Biol 2003, 74(5):635-64l.

3. Dybul M, Daucher M, Jensen MA, Hallahan CW, Chun TW, Belson M, Hidalgo B, Nickle DC, Yoder C, Metcalf JA, Davey RT, Ehler L, KressRock D, Nies-Kraske E, Liu S, Mullins JI, Fauci AS: Genetic characterization of rebounding human immunodeficiency virus type I in plasma during multiple interruptions of highly active antiretroviral therapy. J Virol 2003, 77(5):3229-3237.

4. Popovic M, Tenner-Racz K, Pelser C, Stellbrink HJ, van Lunzen J, Lewis G, Kalyanaraman VS, Gallo RC, Racz P: Persistence of HIVI structural proteins and glycoproteins in lymph nodes of patients under highly active antiretroviral therapy. Proc Natl Acad Sci U S A 2005, I 02(4I): |4807-148I2.

5. Bhoopat L, Rithaporn TS, Khunamornpong S, Bhoopat T, Taylor CR, Thorner PS: Cell reservoirs in lymph nodes infected with HIV. I subtype E differ from subtype B: identification by combined in situ polymerase chain reaction and immunohistochemistry. Mod Pathol 2006, I 9(2):255-263.

6. Siliciano JD, Lai J, Callender M, Pitt E, Zhang H, Margolick JB, Gallant JE, Cofrancesco J Jr., Moore RD, Gange SJ, Siliciano RF: Stability of the latent reservoir for HIV-I in patients receiving valproic acid. J Infect Dis 2007, I95(6):833-836.

7. Brooks DG, Hamer DH, Arlen PA, Gao L, Bristol G, Kitchen CM, Berger EA, Zack JA: Molecular characterization, reactivation, and depletion of latent HIV. Immunity 2003, I 9(3):4I3-423.

8. Aquaro S, Bagnarelli P, Guenci T, De Luca A, Clementi M, Balestra E, Calio $R$, Perno CF: Long-term survival and virus production in human primary macrophages infected by human immunodeficiency virus. J Med Virol 2002, 68(4):479-488.

9. Schmidtmayerova $H$, Nottet HS, Nuovo G, Raabe T, Flanagan CR, Dubrovsky L, Gendelman HE, Cerami A, Bukrinsky M, Sherry B: Human immunodeficiency virus type $I$ infection alters chemokine beta peptide expression in human monocytes: implications for recruitment of leukocytes into brain and lymph nodes. Proc Natl Acad Sci U S A 1996, 93(2):700-704.

10. Meltzer MS, Skillman DR, Gomatos PJ, Kalter DC, Gendelman HE: Role of mononuclear phagocytes in the pathogenesis of human immunodeficiency virus infection. Annu Rev Immunol 1990, 8: 169-194.

II. Gartner S, Markovits P, Markovitz DM, Kaplan MH, Gallo RC, Popovic $M$ : The role of mononuclear phagocytes in HTLV-III/LAV infection. Science 1986, 233(4760):215-219.

12. Aquaro S, Calio R, Balzarini J, Bellocchi MC, Garaci E, Perno CF: Macrophages and HIV infection: therapeutical approaches toward this strategic virus reservoir. Antiviral Res 2002, 55(2):209-225.

13. Perno CF, Aquaro S, Rosenwirth B, Balestra E, Peichl P, Billich A, Villani N, Calio R: In vitro activity of inhibitors of late stages of the replication of HIV in chronically infected macrophages. J Leukoc Biol 1994, 56(3):381-386. 
14. Zhang M, Li X, Pang X, Ding L, Wood O, Clouse K, Hewlett I, Dayton Al: Identification of a potential HIV-induced source of bystander-mediated apoptosis in $\mathbf{T}$ cells: upregulation of trail in primary human macrophages by HIV-I tat. J Biomed Sci 200I, 8(3):290-296.

15. Zhang M, Drenkow J, Lankford CS, Frucht DM, Rabin RL, Gingeras TR, Venkateshan C, Schwartzkopff F, Clouse KA, Dayton AI: HIV regulation of the IL-7R: a viral mechanism for enhancing HIV-I replication in human macrophages in vitro. J Leukoc Biol 2006, 79(6): $1328-1338$

16. Khati M, James W, Gordon S: HIV-macrophage interactions at the cellular and molecular level. Arch Immunol Ther Exp (Warsz) 200I, 49(5):367-378.

17. Singh IN, Goody RJ, Dean C, Ahmad NM, Lutz SE, Knapp PE, Nath A, Hauser KF: Apoptotic death of striatal neurons induced by human immunodeficiency virus-I Tat and gp I 20: Differential involvement of caspase-3 and endonuclease G. I Neurovirol 2004, I0(3):|4|-|5|.

18. Shi B, Raina J, Lorenzo A, Busciglio J, Gabuzda D: Neuronal apoptosis induced by HIV-I Tat protein and TNF-alpha: potentiation of neurotoxicity mediated by oxidative stress and implications for HIV-I dementia. I Neurovirol 1998, 4(3):28I-290.

19. Mattson MP, Haughey NJ, Nath A: Cell death in HIV dementia. Cell Death Differ 2005, I 2 Suppl I:893-904.

20. Kruman, Nath A, Mattson MP: HIV-I protein Tat induces apoptosis of hippocampal neurons by a mechanism involving caspase activation, calcium overload, and oxidative stress. Exp Neurol 1998, 154(2):276-288.

21. Chugh P, Bradel-Tretheway B, Monteiro-Filh CMR, Planelles V, Maggirwar SB, Dewhurst S, Kim B: Akt inhibitors as an HIV-I infected macrophage-specific anti-viral therapy. Retrovirology 2008, 5(I): II.

22. Aquaro S, Muscoli C, Ranazzi A, Pollicita M, Granato T, Masuelli L, Modesti A, Perno CF, Mollace V: The contribution of peroxynitrite generation in HIV replication in human primary macrophages. Retrovirology 2007, 4:76.

23. Chugh P, Fan S, Planelles V, Maggirwar SB, Dewhurst S, Kim B: Infection of human immunodeficiency virus and intracellular viral Tat protein exert a pro-survival effect in a human microglial cell line. J Mol Biol 2007, 366(I):67-8I.

24. Kan H, Xie Z, Finkel MS: HIV gp I 20 enhances NO production by cardiac myocytes through p38 MAP kinase-mediated NFkappaB activation. Am J Physiol Heart Circ Physiol 2000, 279(6): $\mathrm{H} 3 \mid 38-43$

25. Polazzi E, Levi G, Minghetti L: Human immunodeficiency virus type I Tat protein stimulates inducible nitric oxide synthase expression and nitric oxide production in microglial cultures. J Neuropathol Exp Neurol 1999, 58(8):825-83I.

26. Zhao ML, Kim MO, Morgello S, Lee SC: Expression of inducible nitric oxide synthase, interleukin-I and caspase-I in HIV-I encephalitis. J Neuroimmunol 200I, I I 5(I-2): I82-I9I.

27. Reynolds A, Laurie C, Mosley RL, Gendelman HE: Oxidative stress and the pathogenesis of neurodegenerative disorders. Int Rev Neurobiol 2007, 82:297-325.

28. Goujon C Riviere L, Jarrosson-Wuilleme L Bernaud J, Rigal D, Darlix JL, Cimarelli A: SIVSM/HIV-2 Vpx proteins promote retroviral escape from a proteasome-dependent restriction pathway present in human dendritic cells. Retrovirology 2007, 4:2

29. Jacquot G, le Rouzic E, David A, Mazzolini J, Bouchet J, Bouaziz S, Niedergang F, Pancino G, Benichou S: Localization of HIV-I Vpr to the nuclear envelope: Impact on Vpr functions and virus replication in macrophages. Retrovirology 2007, 4(I):84.

30. Palamara AT, Perno CF, Aquaro S, Bue MC, Dini L, Garaci E: Glutathione inhibits HIV replication by acting at late stages of the virus life cycle. AIDS Res Hum Retroviruses 1996, I2(16): I537-I54I.

31. Garaci E, Aquaro S, Lapenta C, Amendola A, Spada M, Covaceuszach $S$, Perno CF, Belardelli F: Anti-nerve growth factor $\mathbf{A b}$ abrogates macrophage-mediated HIV-I infection and depletion of CD4+ T lymphocytes in hu-SCID mice. Proc Natl Acad Sci U S A 2003, 100(15):8927-8932.
Publish with Biomed Central and every scientist can read your work free of charge

"BioMed Central will be the most significant development for disseminating the results of biomedical research in our lifetime. "

Sir Paul Nurse, Cancer Research UK

Your research papers will be:

- available free of charge to the entire biomedical community

- peer reviewed and published immediately upon acceptance

- cited in PubMed and archived on PubMed Central

- yours - you keep the copyright
Biomedcentral 